\title{
Wokół najnowszej polskiej refleksji nad dziejami językoznawstwa
}

\section{Around the recent Polish reflection on the history of linguistics}

\author{
Wtadystaw Zabrocki \\ INSTYTUT JĘZYKOZNAWSTWA, UNIWERSYTET IM. ADAMA MICKIEWICZA \\ AL. NIEPODLEGŁOŚCI 4, 61-874 POZNAŃ \\ zabrocki@amu.edu.pl
}

\begin{abstract}
The purpose of the article is a critical reflection on the issues raised in two high-profile books on the history of reflection on language (word) published in Poland in 2016.
\end{abstract}

\section{Streszczenie}

Celem artykułu jest krytyczna refleksja nad poruszoną w dwóch głośnych książkach wydanych w Polsce w 2016 roku problematyką historii refleksji nad językiem i słowem.

W tej części bogatej bibliografii Profesora Tadeusza Zgółki, która jest poświęcona filozoficzno-metodologicznej refleksji nad dziejami językoznawstwa światowego, wyróżnia się, moim zdaniem, teoretyczny szkic dziejów lingwistyki, który znajdujemy w szeroko znanym poznańskim wprowadzeniu do językoznawstwa napisanym we współautorstwie z Jerzym Bańczerowskim i Jerzym Pogonowskim (Bańczerowski, Pogonowski, Zgółka: 1982).

W myśl dokonanej tam periodyzacji dziejów lingwistyki swoistym zwieńczeniem i ukoronowaniem prowadzonych w dziejach myśli ludzkiej dociekań językoznawczych jest odkrycie społecznej kompetencji komunikacyjnej - jako przedmiotu badań lingwistyki przekraczającej próg zaawansowania teoretycznego. Metalingwistycznej teorii tak rozumianej kompetencji poświęcił Tadeusz Zgółka osobną monografię (Zgółka: 1980). Innym ważnym ustaleniem przyjętym przez Profesora było rozumienie 
postępu na drodze do ukonstytuowania się badań nad kompetencją jako uporządkowanej drogi rozwoju kolejno następujących paradygmatów myśli językoznawczej. Myśl ta obecna jest już w programowym tekście Jerzego Kmity (Kmita: 1978) stanowiącym ramowy szkic dziejów lingwistyki współczesnej (naukowej), gdzie wyróżniono paradygmat historycznoporównawczy, strukturalistyczny i generatywistyczny. Ten ostatni, zdaniem Kmity, reprezentuje etap przełomu teoretycznego w lingwistyce.

W roku 2016 ukazały się na polskim rynku wydawniczym dwie ważne pozycje z zakresu filozoficznej refleksji nad językiem. Jedna to będąca przedmiotem niniejszej dyskusji opublikowana w Poznaniu FILOZOFIA SŁOWA. ZARYS DZIEJÓW Bolesława Andrzejewskiego, a druga pozycja to opublikowane w Warszawie dwutomowe dzieło Andrzeja Bogusławskiego i Ewa Drzazgowskiej JEZZYK W REFLEKSJI TEORETYCZNEJ. PRZEKROJE HISTORYCZNE .

W obydwu książkach zabrakło odniesienia do wspomnianej powyżej istotnej, moim zdaniem, perspektywy paradygmatycznego ujęcia dziejów lingwistyki (w tym jej filozoficznych założeń ).

Nawiasem mówiąc, również w roku 2016 w Krakowie ukazał się znakomity PRZEWODNIK PO FILOZOFII JĘZYKA pod redakcją Joanny OdrowążSypniewskiej. Jest to jednak dzieło zasadniczo inne od wymienionych uprzednio. Praca ta bowiem dotyczy aktualnego stanu wiedzy w zakresie podstawowych problemów filozofii języka. Nie jest w żadnej mierze poświęcona historii językoznawstwa, czy obecności refleksji nad językiem w dziełach filozofów przeszłości. To pierwsze, moim zdaniem, jest zakresem dociekań zwłaszcza autorów dzieła JEZZYK W REFLEKSJI. TEORETYCZNEJ, a to drugie tworzy problematykę książki FILOZOFIA SEOWA.

Porównanie tych dwóch ostatnich dzieł też jest ryzykowne, ponieważ są przeznaczone dla różnych czytelników. Książka Bogusławskiego i Drzazgowskiej to wielce erudycyjny przegląd myśli z pogranicza filozofii i teoretycznego językoznawstwa, obejmujący całość światowej refleksji na ten temat powstałej w różnych kulturach na przekroju dwóch i pół tysiąca lat. Dzieło Andrzejewskiego ograniczone jest do kultury śródziemnomorskoeuropejskiej i stanowi, jak zaznacza sam Autor we wstępie, wykład często encyklopedyczny, podręcznikowy. W dziele Bogusławskiego i Drzazgowskiej dominuje interpretacja adaptacyjna, natomiast książka Andrzejewskiego jest niemal wzorcowym przykładem stosowania interpretacji historycznej. Autor wiernie, acz często skrótowo, rekonstruuje związane z językiem poglądy wielkich filozofów, poczynając, jak to się utarło w wykładach $\mathrm{z}$ dziejów refleksji filozoficznej, od filozofów jońskich. W książce Andrzejewskiego znajdujemy zdecydowanie więcej filozofii, a książka Bogusławskiego i Drzazgowskiej charakteryzuje się przewagą myśli teoretyczno-językoznawczej nad filozoficzną.

Obydwie pozycje ograniczają swój przedmiot rozważań do mniej więcej końca lat 60. XX wieku. Przy tym w całym dziele Bogusławskiego i Drzazgowskiej przewijają się wątki ocenne związane $\mathrm{z}$ obecnością $\mathrm{w}$ omawianej, bardzo szerokiej perspektywie filozoficzno-językoznawczej 


\section{Władysław Zabrocki: Wokót najnowszej polskiej refleksji nad dziejamijęzykoznawstwa}

elementów własnej koncepcji Andrzeja Bogusławskiego, a u Andrzejewskiego znajdujemy tylko bezosobowo wspomnianą na kilku stronach jego koncepcję homo uniwersalis.

W obydwu dziełach natomiast doskwiera niewielka ilość informacji o rodzimych dokonaniach na gruncie filozoficznej refleksji nad językiem. Wspomnę tylko brak w dziele Andrzejewskiego Mikołaja Rudnickiego (jednego z założycieli UP) czy kontynuatora myśli lwowsko-warszawskiej Tadeusza Batoga, którego uczniem jest też stosujący formalne metody w językoznawstwie Jerzy Bańczerowski do dzisiaj bardzo aktywny naukowo, mimo skończonych niedawno 80 lat. Obok rozdziału o polskiej filozofii słowa zabrakło mi też rozdziału omawiającego współczesny spór o status ontologiczny języka.

Z uznaniem chciałbym natomiast odnotować obecność w książce Andrzejewskiego rozdziału 10 Język $w$ świetle materializmu dialektycznego.

U Bogusławskiego takiego rozdziału nie ma. Znajdujemy natomiast ciekawy cytat z Dialektyki przyrody świadczący, zdaniem Bogusławskiego o wyjątkowym niezrozumieniu przez klasyków problematyki nauk o języku: Dialektyka przyrody (Marks, Engels: 1969): „[o psach] [...] kto miał wiele do czynienia z takimi zwierzętami, niełatwo oprze się przekonaniu, iż teraz często odczuwają one niezdolność do mówienia jako brak. [...] Wszakże tam, gdzie organ głosowy istnieje, niezdolność ta w pewnych granicach znika. Dziób ptaka różni się zasadniczo od odpowiedniego organu człowieka, a jednak ptaki są jedynymi stworzeniami, które mogą nauczyć się mówić; a ptak o najwstrętniejszym głosie, papuga, mówi najlepiej. I nie opowiadajcie, że nie rozumie ona tego, co paple. [...] w granicach swego rozeznania może nauczyć się rozumieć to, co mówi. Nauczcie papugę obelżywych słów, tak żeby nabrała pojęcia o ich znaczeniu [...] podrażnijcie ją, a niebawem przekonacie się, że umie stosować obelżywe słowa nie mniej trafnie niż berlińska przekupka. Podobnie - gdy żebrze o łakocie.”

Wspomnę tutaj, jako ciekawostkę, że recenzenci angielskiego wydania słynnych Zagadnień i kierunków filozofii Ajdukiewicza podkreślali jako zaletę w stosunku do obecnych na rynku anglosaskim wprowadzeń do filozofii omówienie u Ajdukiewicza materializmu dialektycznego i historycznego.

Bogusławski wspomina też o marksistowskich teoriach Marra.

Nie ma natomiast ani u Andrzejewskiego, ani u Bogusławskiego żadnej wzmianki o będącej przez pewien czas przewodnikiem metodologicznym dla językoznawców z obozu państw socjalistycznych pracy Józefa Stalina Marksizm a zagadnienia językoznawstwa, która w rozsądny sposób mitygowała szaleństwa marksistowskie Marra na rzecz klasycznego językoznawstwa historyczno-porównawczego

Niestety, strukturalizm nie miał już tego szczęścia. Stalinowska lingwistyka radziecka potępiała pojęcie fonemu tak samo intensywnie, jak pojęcie genu.

Dosyć nieoczekiwany wspólny wątek znajdujemy w wyrażonej pod koniec dzieła deklaracji Bogusławskiego, że język pozwala ludziom „na współdziałanie z Bogiem, dawcą zdolności językowej, w rządach nad tym 
wszechświatem, do którego należymy". U Andrzejewskiego mamy szeroko omówione poglądy średniowiecznych mistyków, a szczególnie bliski wydaje się poglądom Bogusławskiego berliński myśliciel oświeceniowy Johann Peter Süssmilch (lub Süßmilch, lub Suessmilch). W rozprawie z 1766 roku napisał on, cytuję za Andrzejewskim s. 85,: „Język jest na tyle doskonały, że mogła go stworzyć tylko istota o jeszcze większym i doskonalszym rozumie, która przewidziała wszelkie zakresy użycia jeżyka i według tego język konstruowała”.

Podobny argument znajdujemy w ramach filozoficznej pespektywy gramatyki generatywno-transformacyjnej Noama Chomsky'ego (Chomsky: 1965, Chomsky: 1993). Z niezwykłej złożoności języka naturalnego (zdaniem Chomsky'ego przewyższającej wyrafinowane teorie matematyczne) wnioskuje się o wrodzoności w zakresie tzw. języka wewnętrznego, nie zaś reguł gramatyki (nawet uniwersalnej). Te ostatnie w nowszych wersjach paradygmatu generatywnego zastępowane są przez uniwersalne sparametryzowane zasady składające się na specjalny językowy organ biologiczny. Nie ma więc zagrożenia przez argument Wittgensteina kwestionujący zasadność postulowania języka prywatnego (kierowanego przez reguły). Tam gdzie Süssmilch przywołuje Boga, tam Chomsky odwołuje się do nauk przyrodniczych. Nie zachodzi więc napięcie, wskazane w FILOZOFII SŁOWA między badaniami Chomsky'ego, a biolingwistyką Lenneberga.

Nie jest też gramatyka generatywna w sensie Chomsky'ego filozoficznym, antyempirycznym komunikacyjnym uniwersalizmem. Opowiedzenie się po stronie racjonalizmu nie wyklucza badań empirycznych. Wspomniana teoria zasad i parametrów dała możliwość napisania głęboko empirycznie ugruntowanych gramatyk wielu języków naturalnych. Natomiast warto podkreślić, że raczej nie stanowią materiału empirycznego dla generatywistów akty komunikacji językowej, czy intuicje dotyczące wykonania językowego lecz intuicje gramatyczne rozumiane czasem jako „głos kompetencji językowej „, nie komunikacyjnej. Osobny problem to zasadność korzystania z intuicji jako danych empirycznych. Chomsky nie wyklucza w przyszłości redukcji swojej lingwistyki do biologii, a nawet fizyki i umniejszenie zdecydowane wagi intuicji jako materiału empirycznego. Natomiast obecnie nie ma innego sposobu testowania empirycznego hipotez generatywistycznych. Należy zaznaczyć, że nie stosują się do tak rozumianej bazy empirycznej zarzuty nie spełniania kryterium intersubiektywności.

W uznaniu rekurencji za podstawową własność uniwersalną nie chodzi o" wyrażanie nieskończonej ilości myślowych pojęć „. Gramatyka Chomsky’ego jest wyrazem sprzeciwu wobec Janowego „ Na początku było słowo”. U Chomsky'ego na początku jest zdanie „S”. W gramatyce Chomsky'ego chodzi o uchwycenie rekurencyjnych mechanizmów generowania zdań. Są to mechanizmy obliczeniowe nie wyrażane obecnie przy pomocy reguł. 
Władysław Zabrocki: Wokót najnowszej polskiej refleksji

nad dziejami językoznawstwa

\section{Bibliografia}

Adjukiewicz, K. (1973). Problems and theories of philosophy.: Cambridge University Press.

Andrzejewski, B. (2016). Filozofia słowa. Zarys dziejów. Poznań:

Wydawnictwo Naukowe UAM.

Bańczerowski, J., Pogonowski, J., \& Zgółka, T. (1982). Wstęp do

językoznawstwa: Skrypt dla studentów studiów uniwersyteckich. Poznań: Wydawnictwo Naukowe UAM.

Bogusławski, A., \& Drzazgowska, E. (2016). Jezyk w refleksji teoretycznej:

Przekroje historyczne. Warszawa: Katedra Lingwistyki Formalnej. Uniwersytet Warszawski.

Chomsky, N. (1965). Aspects of the theory of syntax. Cambridge, Mass.

Chomsky, N. (1993). Lectures on government and binding: The Pisa lectures. Berlin: Mouton de Gruyter.

Kmita, J. (1978). O naukowo-teoretycznym ujęciu kultury symbolicznej. W:

J. Kmita ( red. ), Zagadnienie przełomu antypozytywistycznego $w$ humanistyce. ( s.59-84 ). Warszawa: PWN.

Lenneberg, E. H. (1984). Biological foundations of language. Malabar, Flor: R.E. Krieger.

Odrowąż-Sypniewska, J. (red.). (2016). Przewodnik po filozofii języka.

Kraków: Wydawnictwo WAM.

Zgółka, T. (1980). Jezyk, kompetencja, gramatyka: Studium z metodologii lingwistyki. Poznań: PWN. 